Valóságos könyvtár - könyvtári valóság. Könyvtár- és információtudományi tanulmányok 2018. Szerk. Kiszl Péter, Csík Tibor.

Budapest, ELTE BTK Könyvtár- és Információtudományi Intézet. 2018. 269-276.

\title{
KÖNYVTÁRI ONTOLÓGIÁK ÉS MÜKÖDÉSÜK A XXI. SZÁZADBAN
}

\section{HUBAY MIKLÓS PÉTER}

Petőfi Irodalmi Múzeum, humáninformatikus, múzeumi könyvtáros

\section{TARTALMI ÖSSZEFOGLALÓ}

A könyvtári világ egyre növekvő kihívására - versenyben maradni a keresőszolgáltatásokkal szemben az információszolgáltatás területén - a XXI. század elejétől egyre inkább úgy tűnik, a szemantikus web technológiája kínálja a megfelelő választ. A világháló informatikai megoldásainak használata a bibliográfiai adatfeldolgozás területén egyre inkább elterjedőben van, a teljes „hatalomátvételhez” azonban fél évszázada alkalmazott gyakorlatokat és szemléletmódot kell elhagyni, ami igen kemény feladat.

A dolgozatban áttekintjük azokat a fontos mérföldköveket, fejlesztéseket, amelyek a könyvtártudományt és az informatikát a szemantikus web felé terelték a múlt század utolsó évei óta. Röviden bemutatjuk az adatok összekapcsolási technológiájának elterjedését a könyvtárakban, ezt követően pedig szót ejtünk e megoldás alapvető alkotóeleméről, az ontológiáról, s példákon keresztül mutatjuk be, miként képezi le egy ilyen szókészlet az emberi gondolkodás alapvetô múveleteit. A tanulmány néhány speciális gyakorlati alkalmazás bemutatásával zárul.

A könyvtárinformatika világa és különösképp a bibliográfiai adatok feldolgozásának és tárolásának gyakorlata alapvető átalakulás előtt áll. Noha a számítógép és a világháló megjelenése óta a szakemberek - könyvtárosok és informatikusok - eszköztára számos új módszerrel gyarapodott, a jelenlegi, napjainkra már elodázhatatlan transzformáció nem csupán valami új megtanulását és bevezetését, hanem paradigmaváltás-szintű szemléletváltást is igényel. Be kell látnunk, hogy a könyvtárakat egyre nagyobb mértékben fenyegeti a veszély, hogy végleg alulmaradnak a webes keresőszolgáltatásokkal szemben, és elveszítik olvasóik jelentős részét. Ennek egyik legfőbb oka a körülbelül fél évszázada világszerte alkalmazott MARC-formátum használata, a megoldást pedig a szemantikus web technológiájának alkalmazása hozza el oly módon, hogy a könyvtári információkat kiszabadítja az OPAC-ok és katalógusszerverek zárt rendszereiből, és oda juttatja, ahol a felhasználók valóban keresik azokat: a World Wide Webre.

Dolgozatomban az új információfeldolgozási paradigma építôköveivel, az ontológiákkal (más néven szótárakkal, szókészletekkel) és azok könyvtári alkalmazásával foglalkozom. A tanulmány első részében rövid áttekintést adok az információs technológia, valamint a könyvtártudomány természetes fejlődésének kapcsolódási pontjairól, bemutatva ezzel a téma előzményeit. Ezt követően vázolom az adat-összekapcsolási 


\section{HubAy MiKLÓs PÉTER}

technika megjelenésének és elterjedésének történetét a könyvtári világban, majd pedig a napjainkban létező szakmai ontológiákból vett példák segítségével bemutatom az emberi gondolkodás formalizálásának, modellezésének legfontosabb informatikai segédeszközeit. A dolgozatot néhány sajátosság bemutatásával zárom.

\section{Elózmények, kapcsolódási pontok}

A szemantikus web alapkövét a W3C által kidolgozott RDF (Resource Description Framework, erőforrás-leíró keretrendszer) adja. A rendszer első, munkaanyag-változata 1997-ben készült el azzal a céllal, hogy segítségével a számítógép számára is érthető, jelentésteli módon lehessen metaadatolni a weben hozzáférhető honlapokat és más dokumentumokat (azaz erőforrásokat - web resources) ${ }^{1}$.

Az RDF-fel három elemből álló állításokat, kijelentéseket fogalmazhatunk meg a leírandó erőforrásokról, amelyek alanyt, tárgyat, valamint a kettôt valamilyen viszonyba hozó állítmányt tartalmaznak. Ezeket a háromelemú állításokat tripletnek nevezzük. Ilyen triplet például, hogy az 1984 címü könyv (alany); szerzöje (állítmány); George Orwell (tárgy). A gép számára alkotott állításokban azonban, szemben ezzel a példával, nem szöveges értékeket használunk. Minden elemet, a kézzelfoghatókat (1984 című könyv, Orwell stb.) és az absztraktan létezőket is (szerzői viszony stb.) egy egységes erőforrásazonosító, egy ún. URI azonosít. Azzal pedig, hogy ezek az URI-k http-alapúak (lásd később), bármit, ami a világon bármilyen formában létezik, a világháló részévé tehetünk, s ami még fontosabb, az RDF használatával lehetővé tesszük a diszkrét adatelemek egymással való összekapcsolását, hivatkozások létrehozását. Tim Berners-Lee, a világháló feltalálója egy 2006-ban megjelent, programadó cikkében vázolta fel az ilyen összekapcsolt (linkelt) adatok jelentőségét és megalkotásuk alapvető követelményeit. Négy szabályt állított fel annak érdekében, hogy a jelentéssel teli világháló valóban élővé legyen:

- URI-k használata a dolgok jelölésére;

- http-alapú URI-k használata, a felkereshetőség érdekében;

- további információk szolgáltatása az URI-król szabványos formátumok (RDF, SPARQL) használatával;

- linkek biztosítása további URI-khoz a továbblépés érdekében. ${ }^{2}$

Az adatok közötti kapcsolatok létrehozásának koncepciójából (linked data) kiindulva épül a jelenleg is ismert World Wide Webnek az a második rétege, amelyet szemantikus web néven ismerünk. Más szavakkal azt is mondhatjuk, hogy napjainkban az egymással összekapcsolódó adatok hálózata a szemantikus web gyakorlati megvalósulási formája. ${ }^{3}$

Kevesen tudják, hogy a dolgok, valamint a dolgok közötti viszonyok formalizálására nem az RDF volt az egyetlen kísérlet. Több évvel az erőforrás-leíró keretrendszer igazi elterjedése előtt, 2001-2002-ben a Stanfordi Egyetemen alkották meg a XOBIS nevű XML-sémát, amelynek számos, igen előremutató alapelvét viszontláthatjuk a kortárs könyvtári informatikában. A XOBIS múködése a különféle bibliográfiai entitások 
és a köztük lévő kapcsolatok leírásán alapszik. A kidolgozók szerint ugyanis bármi, ami a világban létezik, tíz különféle entitástípusba sorolható be, amelyeket a séma principal elementnek (főelemnek) nevez, s ezek között az entitások között a legkülönfélébb kapcsolatok állhatnak fenn. Mivel bármelyik típus elemei kapcsolódhatnak bármelyik másikhoz, összesen száz különféle kapcsolattípus létezik a XOBIS-on belül, amelyeket részletesen jellemezhetünk a rendelkezésre álló XML-jelölőkkel: megadhatjuk egyebek mellett a kapcsolat típusát (hozzá-, fölé-, alá-, mellérendelő stb.), megnevezését (fogalmi, földrajzi, kronológiai stb.), erôsségét (például egy mű fö- és melléktémái, elsődleges és további szerzők stb.). ${ }^{4}$ Sajnos a XOBIS-séma - vélhetően igen bonyolult szerkezete miatt - nem terjedt el szélesebb körben, a jelenkori technológiákkal mutatott erôteljes hasonlósága miatt azonban méltó a figyelemre.

A könyvtártudomány területét vizsgálva természetesen meg kell említeni a MARCformátumot, helyesebben a vele szemben érzett, a világháló megjelenése óta egyre növekvő mértékű elégedetlenséget. Bár jelentősége ma is megkérdőjelezhetetlen, egyre többen és egyre gyakrabban róják fel hibájául elavult adatszervezését, a könyvtári világ miatta történő elszigetelődését (ti. könyvtári területen kívülre történő adatszolgáltatáshoz igen nehézkes konverziós eljárásokra van szükség), az elektronikus dokumentumok több szempontból is problémás kezelését, illetve hogy a segítségével tárolt adatok a keresőszolgáltatások számára láthatatlanok, a mélyweb tartományába kerülnek. ${ }^{5}$ További probléma, hogy a MARC nem tart lépést a katalogizálás elméletének fejlődésével: nem alkalmas az FRBR entitásközpontú szemléletének megfelelő leképezésére. A bibliográfiai rekordok funkcionális követelményeit leíró FRBR-modellt (Functional Requirements for Bibliographic Records) az IFLA dolgozta ki az 1990-es évek második felében, s ez a modell teljesen új alapokra, entitások és kapcsolataik leírására helyezi a hangsúlyt a dokumentum-feldolgozásban. A modellben definiált három entitáscsoport közül az első a legismertebb, ennek köszönhetjük a bibliográfiai univerzumban a mü, kifejezési forma, megjelenési forma és példány fogalmak megjelenését. ${ }^{6}$ A funkcionális követelmények vizsgálatát a 2000-es években a besorolási adatok, továbbá a tárgyszavak tekintetében is elvégezték, ennek eredménye az FRAD és FRSAD néven ismert két modell. Az FRBR-t, FRAD-t és FRSAD-t a közelmúltban átdolgozták és egységesítették, valamint felszámolták a közöttük feszülő ellentmondásokat, amelyek a részmodellek egymástól elkülönülő fejlesztéséből következtek: így született meg 2017 második felében egy átfogó, a dokumentumfeltárás minden területét lefedő fogalmi modell, a Library Reference Model (LRM). ${ }^{7}$

Az FRBR-ben megfogalmazott négy alapentitást - és főként azok kapcsolatait a közelmúltban, illetve napjainkban érvényben lévő katalogizálási szabályzatok (ISBD, AACR2) nem képesek kielégítő módon kezelni. Ezt a felismerést alapul véve az angolamerikai nyelvterületen dolgozó könyvtárosok teljesen, az alapjaitól kezdve átdolgozták az AACR2-t, az új változatnak pedig az RDA (Resource Description and Access) nevet adták. Ez a szabályzat már teljes egészében a funkcionális modellben leírt entitásokra épül, ezek mentén építve fel a katalogizálási munkafolyamatot. Az így elkészült leírások 


\section{HubAy MiKLÓs PÉTER}

hordozására a MARC - mint korábban említettük - nem, vagy nagyon kevéssé alkalmas, így az RDA elterjedése ugyancsak a linked data alapú feldolgozás malmára hajtja a vizet.

\section{A linked data elterjedése a könyvtári világban}

A szemantikus webes technológiát alkalmazó metaadatolás története a könyvtári szférában a Dublin Core-ral (DC) kezdődik. Mint ismeretes, a DC-t megalkotói - könyvtárosok, elektronikusforrás-szakértők, valamint tartalomszolgáltatók - azzal a szándékkal dolgozták ki 1995-ben, hogy segítséget nyújtsanak az elektronikus dokumentumok, webdokumentumok egyszerű és gyors metaadatolásához. Az eredeti készletet, mely 15 elemet tartalmazott - cím, szerző, kiadó, nyelv, formátum stb. - az ezredfordulón az RDF segítségével is definiálták, s a Dublin Core-ból vett példák hamarosan az RDF alapdokumentumainak állandó részeivé váltak. Így voltaképpen a DC tekinthető az első, könyvtári felhasználásra (is) alkalmas ontológiának - azaz a dokumentumfeldolgozás területén alkalmazható relációk készletének -, és könnyen beláthatjuk, hogy a közös cél miatt egyáltalán nem meglepő a két igen fiatal technológia egymásra találása. (2000-ben a DC öt, az RDF pedig mindössze kétéves volt).

Ahogy növekedett az ontológiaépítés eszköztára (RDFS, OWL és más technológiák), úgy szaporodtak gombamódra a különféle szókészletek; minden egyes ontológiaalkotó más és más módon válogatta, hierarchizálta és formalizálta a dokumentumleírás során előforduló különféle viszonyokat (előzmény címe, folytatása, kiadója, oldalszáma stb.) Így született meg a XXI. század első másfél évtizedében a MARCOnt, a BIBO, a BIBLIO, a BIBFRAME, a bibliotek-o, az LD4L, az FRBRe - és a sort még folytathatnánk, hiszen e tanulmány írásának idején (a szerző kutatásait alapul véve) legalább 20-30 különféle, alapvetően dokumentumok könyvtári igényességű metaadatolására használható szókészlet létezik. A linked data (kapcsolt adatok) technológiája azonban megengedi, sőt kifejezetten javallja, hogy egyazon erőforrás leírásakor az alkalmazott relációk minél több szótárból származzanak, hiszen a nagyobb mérvű összekapcsolódás jótékony hatással van a globális adathálózatra (vö. Tim Berners-Lee negyedik alapelvével).

A relációk formalizált alakját tartalmazó ontológiákon kívül a könyvtári világban használatosak ún. szemantikus elemkészletek is, amelyek különféle entitásokat tartalmaznak (például a VIAF személyeket, a Geonames földrajzi helyeket, az RDA elemkészletei például információhordozókat, megjelenési gyakoriságokat, a Kongresszusi Könyvtáréi pedig például nyelvkódokat), s az ezeket azonosító URI-k az RDF háromelemú állításaiban alanyként vagy tárgyként alkalmazhatók.

Az ontológiák és a szemantikus elemkészletek (más néven: értékszótárak) felhasználásával a könyvtári katalógusokban felhalmozott adatvagyon könnyedén konvertálható, illetve közzétehető a szemantikus weben, biztosítva ezzel az adatok újrafelhasználásának lehetőségét. Az adathálózat élővé, múködővé tétele érdekében egyre több könyvtár végez ilyen publikációt: közülük mindenképpen érdemes megemlíteni az Országos Széchényi 
Könyvtárat. Az intézmény, akkori informatikai igazgatója, Horváth Ádám munkájának köszönhetően, a világon másodikként végezte el ezt a közzétételt (három névtér, a DC, a FOAF és a SKOS használatával). Az első helyet a svéd közös katalógus, a LIBRIS üzemeltetői tudhatják magukénak, akik az egyik korai könyvtári ontológiát, a BIBO-t is igénybe vették az adatkonverziós munkához. Ma már több multifunkciós keretrendszer áll a könyvtárosok rendelkezésére - ilyenek például az ALIADA, a Library.Link Network, vagy a BLUECloud Visibility - amelyek a szemantikus weben történő adatpublikáció minden fázisát, a konverziót, a feltöltést és a különféle regiszterekbe, nyilvántartásokba való bejegyzést is elvégzik, sőt, képesek arra, hogy más névterekből származó adatokkal gazdagítsák is a kiinduló adatkészletet.

\section{A gondolkodás modellezése az ontológiákban}

Az ontológiának talán a legnagyobb haszna és legelőremutatóbb lehetősége, hogy segítségével a számítógép a benne tárolt információk felhasználásával automatikus következtetések elvégzésére válik képessé az egyes leírandó erőforrások esetében. Ennek érdekében az ontológiaépítő nyelvek igyekeznek a lehető legjobban modellezni az emberi gondolkodás alapmúveleteit, s közülük legfő́képpen az osztályozást, azaz a dolgok csoportokba sorolását közös jellemzőik mentén. Ehhez azonban elsőként létre kell hozni a szükséges osztályok hierarchiáját, amely mentén a következtetések a későbbiekben felépíthetők. Például, ha egy elem tagja egy A osztálynak, ugyanakkor A osztály minden eleme tagja egy B osztálynak, akkor a konkrét elem is tagja a B osztálynak. Humán ágensek számára az állítás igazságtartalma könnyen belátható, a gépet azonban „meg kell tanítani” rá, hogy ezt a kapcsolatot felismerje: az osztályok kialakítása mellett azok legkülönfélébb alá- és mellérendeltségi viszonyainak modellezését is el kell végezni. Könyvtártudományi szókészletekben gyakran találkozhatunk ilyen és hasonló osztályhierarchiákkal:

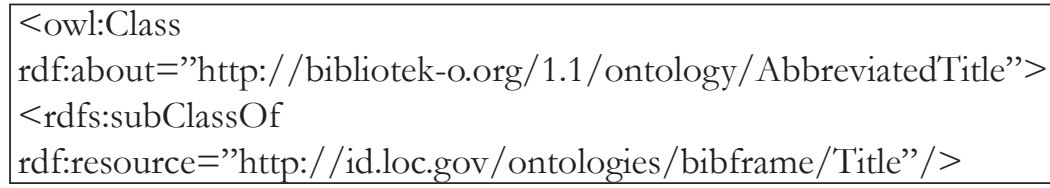

A kódrészlet, amely az RDF alapkészletének, valamint az RDFS sémanyelvnek a felhasználásával készült, egy osztály deklarációjának módját ábrázolja: létrehozzuk az AbbreviatedTitle (rövidített cím) osztályt, és azt is rögtön meghatározzuk, hogy a rövidített címek osztálya a Title (cím) osztály alosztálya is egyben.

Az egyes konkrét erőforrások osztályba sorolását ezt követően egy, az RDF alapkészletben megtalálható reláció, az rdf:type segítségével végezzük el. 
rdf:about="http://bibliotek-o.org/1.1/ontology/cancelled"> rdf:type

rdf:resource="http://id.loc.gov/ontologies/bibframe/Status"/>

A fent látható rövid kódrészlet jelentése, hogy a „cancelled” megjelölésű erőforrást azaz a „törölt”” névvel jelölt tulajdonságot - besoroljuk a példánystátuszok osztályába. (Az áttekinthetőség és az ember általi értelmezhetőség kedvéért az rdf:type karaktersorozatot gyakran helyettesítik ,a”-val, közelebb hozva az adatszerkezetet az angol nyelvü mondat struktúrájához: „cancelled (is) a status”.)

Hasonlóképpen járunk el a tulajdonságok, viszonyok (azaz olyan elemek, melyek csak állítmányként fordulhatnak elő a tripletekben) deklarálásakor is: kijelenthetjük például, hogy az "ISBN-je valaminek” reláció az „azonosítója valaminek” viszony alárendelt relációja.

<rdf:Property rdf:about="http://bibframe.org/vocab/isbn">

$<$ rdfs:subPropertyOf

rdf:resource="http://bibframe.org/vocab/identifier"/>

A tulajdonságok deklarálásakor - a kívánt hierarchiaviszonyok megadásán túl - még két paramétert kell meghatározni: értelmezési tartományukat (domain, azaz egy osztály, amelynek tagjaira a tulajdonság alkalmazható), illetve értékkészletüket (range, amilyen típusú értékeket a tulajdonság felvehet). Ezt illusztrálja a következő példa:

<owl:DatatypeProperty rdf:about="http://id.loc.gov/ontologies/bibframe/musicKey">
rdfs:domain rdf:resource="http://id.loc.gov/ontologies/bibframe/Work"/>
rdfs:range
rdf:resource="http://www.w3.org/2000/01/rdf-schema\#Literal" / >

A fenti példában a „hangnem” tulajdonság értelmezési tartománya - nyilvánvalóan - a művek osztálya, azaz hangneme csak zeneműveknek lehet; míg az értékkészlet megadásával azt fejezzük ki, hogy a tulajdonság értéke csak valamilyen szabad szöveges érték, azaz literál lehet.

A 2000-es évek első felében, a W3C által közreadott OWL (Web Ontology Language) sokkal összetettebb fogalmi rendszerek leképezésére is lehetôséget ad, mint az RDF és az RDF sémanyelv. Segítségével többek között megalkothatjuk az osztályok metszetét (owl:intersectionOf), unióját (owl:unionOf), azonosságot fejezhetünk ki két erőforrás között (owl:sameAs), leírhatjuk két halmaz diszjunktságát (owl:disjointWith), valamint inverz viszonyokat állíthatunk fel (owl:inverseOf). ${ }^{8}$ Az OWL webontológianyelv ezen kívül nagyon sok adattípus-definíciós, valamint korlátozási-szúkítési lehetőséggel rendelkezik, ezek felhasználásával igen jól használható segédeszközzé válik a legkülönfélébb, helyenként igen komplex fogalmi területek modellezéséhez. 


\section{Nébány gyakorlati kérdés}

E tanulmány egy korábbi pontján már említettük, hogy a linked data technológiája szorgalmazza, hogy az egyes erőforrások leírásakor használt relációk minél több szótárból származzanak, így erôsítve a globális adatháló összefonódottságát. Emellett pedig nyilvánvaló, hogy jelentős mennyiségű munkát takarítunk meg, ha már korábban, más szótárakban definiált relációkat nem készítünk el mi magunk is, hanem egyszerűen beemeljük azokat a saját rendszerünkbe. Ez azonban nem minden esetben történik így. A Kongresszusi Könyvtár által kidolgozott BIBFRAME keretrendszer például, amely a szakemberek reménye szerint ezúttal már valóban leváltja a MARC-ot, minden relációra saját definíciót alkot, még olyanokra is, amelyek például a Dublin Core szótárában már megtalálhatók (mint például a hasPart, vannak részegységei). Ugyan ezzel a gyakorlattal teljesebbé, egységesebbé válhatnak az egyes szótárak, alkalmazása mégsem javasolt, mivel ellentmond a linked data egyik, Tim Berners-Lee által lefektetett alapelvének. Robert Sanderson, a BIBFRAME egyik legnagyobb kritikusa részletes elemzést közölt a Kongresszusi Könyvtár szókészletének hibáiról ${ }^{9}$, majd munkatársaival kidolgozta a LD4L (Linked Data for Libraries) ontológiát, s az ontológiaépítés során igyekezett elkerülni a BIBFRAME-ben felfedezett hibákat. Az újrafelhasználás tekintetében mindenképpen sikerült előrébb lépnie: az LD4L ontológia Dublin Core-ból, a FaBiO-ból, valamint a schema.org-ból származó relációkat is alkalmaz.

Az RDF-dokumentumok elején - akármilyen szerializációs szintaxist alkalmazunk - mindig található névtérdeklaráció: a dokumentum előállításához felhasznált építőelemek, relációk származási helyei. Tartalmában és funkciójában ez a rész egyaránt emlékeztet egy tárgymutatóra és egy irodalomjegyzékre, s bár teljes mértékben egyikkel sem azonos, áttanulmányozása mégis sokat elárul a konverziós szoftver vagy éppen a natív adatelőállítási felület fejlesztőinek gondolkodásáról, modellezési elképzeléseiről.

A korábban már említett, szemantikus adatpublikációt segítő ALIADA projekt által kidolgozott algoritmus MARC-ban, LIDO-ban, valamint DC-ben tárolt adatokat képes fogadni. Egy részletes mapping határozza meg, hogy az eredeti adatelemeket milyen szótárak milyen relációinak felhasználásával kell RDF-állításokká konvertálni. Az átalakítás során a könyvtártudomány területének relációit az FRBRoo, a SKOS-SKOSXL, valamint a DCTERMS ontológiák adják. ${ }^{10}$ A MEK, valamint az OSZK Digitális Képarchívuma pedig igen sokat merített a BIBO ontológiából, a személyneveket tartalmazó VIAF-ból, de a földrajzi nevekhez is két elemkészletet, valamint több, a Kongresszusi Könyvtár által kidolgozott értékszótárat is felhasznál. ${ }^{11}$

Bár a könyvtári területen megvalósuló implementációk száma örvendetesen emelkedik, a szerző meglátása szerint még mindig csak első szakaszában van a bibliográfiai adatok ontológialapú feldolgozási és szolgáltatási technológiájának fejlődése. Nehéz tehát biztos jóslatot mondani arról, megvalósulnak-e az ambiciózus célok: a technikai kötöttségektől megszabadulva integrálni a könyvtári információkat a felhasználók által 


\section{HubAy MiKLÓs PÉTER}

is jól ismert, kereshető és egyre természetesebben használt közegbe. Csak remélni tudjuk, hogy a könyvtárosok szűkebb szakmai, valamint informatikai ismeretének, továbbá proaktivitásának köszönhetően ez előbb-utóbb megvalósul.

\section{Jegyzetek}

1. Resource Description Framework (RDF). Model and Syntax. Forrás: https://www.w3.org/ TR/WD-rdf-syntax-971002 [2018. január. 6.]

2. BERNERS-LEE, Tim: Linked Data. Forrás: https://www.w3.org/DesignIssues/LinkedData. html [2018. január 6.]

3. SOLODOVNIK, Iryna: Development of a metadata schema describing institutional repository content objects enhanced by "LODE-BD" strategies. = Italian Journal of Library and Information Science, 4 vol. 2. no. 2013. 109-144. p. Forrás: https://doi.org/10.4403/jlis. it-8792

4. MILLER, Dick R.: XOBIS-An Experimental schema for unifying bibliographic and authority Records. = Cataloging and Classification Quarterly, 39. vol. 3-4. no. 2005. 285-303. p. https://doi.org/10.1300/j104v39n03_18 [2018. július 27.]

5. HUBAY Miklós: A BIBFRAME és a könyvtári feldolgozás új keretei. Forrás: http://mek. oszk.hu/15600/15678/15678.pdf [2018. január. 6.]

6. DUDÁS Anikó: Forrásleírás és hozzáférés: az új angol-amerikai katalogizálási szabályzat (RDA) és kritikája. = Könyvtári Figyelő, 58. évf. 4. sz. 2012. 727-750. p.

7. IFLA Library Reference Model (LRM). Forrás: https://www.ifla.org/publications/node/11412 [2018.január 6.]

8. OWL Web Ontology Language : Reference. Forrás: https://www.w3.org/TR/owl-ref [2018. január. 13.]

9. SANDERSON, Robert: Analysis of the BIBFRAME ontology for linked data best practices. Forrás: https://docs.google.com/document/d/1dIy-FgQsH67Ay0T0O0ulhyRiKjpf_ I0AVQ9v8FLmPNo/edit\# heading=h.310o1a8282cm [2018. január. 13.]

10. HORVÁTH Ádám: Gondolatok a szemantikus webről és egyben az ALIADA szoftverről. = Könyvtári Figyelő, 61. évf. 3. sz. 2015. 319-326. p.

11. DRÓTOS László: Szemantikus web fejlesztések a MEK-ben és a DKA-ban. Forrás: http:/ / mek.oszk.hu/html/irattar/eloadas/2017/szemantikus_web_MEK-DKA.ppt [2018. január. 13.]

Hubay Miklós Péter humáninformatikus, múzeumi könyvtáros, a Petőfi Irodalmi Múzeum munkatársa. Az ELTE Irodalomtudományi Doktori Iskola Könyvtártudományi Doktori Programjának hallgatója, kutatási területe a szemantikus web technológiája, metaadat-formátumai, valamint az ontológia alapú bibliográfiai adatfeldolgozás. 